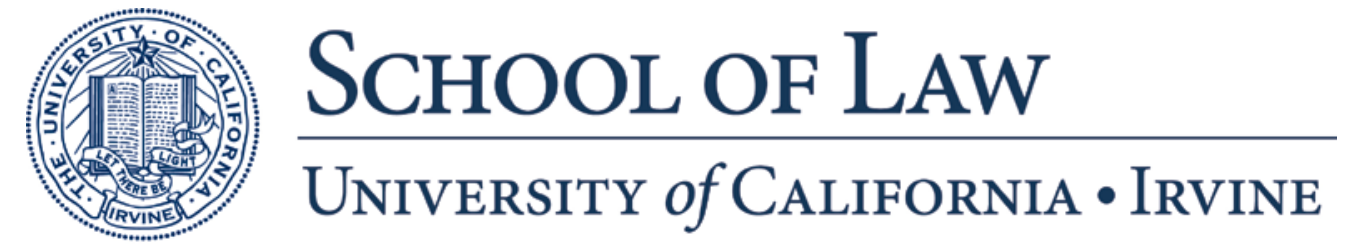

Legal Studies Research Paper Series No. 2014-34

\title{
ARCHIVING JUSTICE: \\ CONCEPTUALIZING THE ARCHIVES OF THE UNITED \\ NATIONS \\ INTERNATIONAL CRIMINAL TRIBUNAL FOR THE \\ FORMER YUGOSLAVIA
}

\author{
David Kaye \\ dkaye@law.uci.edu \\ University of California, Irvine School of Law
}

The paper can be downloaded free of charge from SSRN at: 


\author{
ARCHIVING JUSTICE: \\ CONCEPTUALIZING THE ARCHIVES OF THE UNITED NATIONS \\ INTERNATIONAL CRIMINAL TRIBUNAL FOR THE FORMER YUGOSLAVIA
}

DRAFT of 17 July 2014

\author{
David Kaye \\ Clinical Professor of Law \\ UC Irvine School of Law \\ 401 East Peltason Drive \\ Irvine, California 92697 \\ 949-824-2427 \\ dkaye@law.uci.edu
}

\begin{abstract}
$\underline{\text { Abstract }}$
The International Criminal Tribunal for the former Yugoslavia (ICTY) will complete its proceedings over the coming years, leaving behind an enormous collection of records. The ICTY archive provides a record of conviction and acquittal, prosecution case and defense response - a vast series of contested facts and arguments. The ICTY winds down with a decidedly mixed reputation, especially among the communities of the Balkans, doing damage to the already-discredited idea of a Tribunal capable of aiding the processes of reconciliation. And yet the UN still speaks of the reconciliatory purposes the ICTY archives may serve. Pursuing reconciliation, however, sets up the archive for failure. It would be better for those establishing the archives to focus on other, attainable goals, taking into account Martha Minow's caution against judicial records that merely "speak for themselves" (1998). This essay provides historical context for the development of the ICTY archives, outlining its two decades of work, and emphasizes the political context from and into which the archives will emerge.
\end{abstract}

Keywords: War crimes, Crimes against humanity, genocide, Balkans, Yugoslavia, Bosnia, Serbia, Croatia, international law, international courts, truth and reconciliation. 


\section{Introduction}

For nearly two decades, the United Nations International Criminal Tribunal for the former Yugoslavia ("ICTY” or "Tribunal”) has adjudicated allegations of war crimes, crimes against humanity, and genocide from the 1990s' wars in the Balkans. Yet The Hague-based Tribunal is something more than a war crimes court. It is a repository of testimony, analysis, judgment, opinion, dissent, contempt, imagery, and memory. Its archives hold the stories of those who suffered through the siege of Sarajevo, the massacres around Srebrenica and in Vukovar, the numerous rape camps Bosnian Serb forces set up around Bosnia in the early 1990s, ethnic cleansing in the Krajina, and much more. It gives voice not only to the victims but also to the accused, those who, like Serb President Slobodan Milošević, repeatedly rejected the Tribunal's authority in lengthy disquisitions before the bench. The Tribunal stores the assessments of diplomats, military officers, international analysts, journalists, and others who brought experience and expertise to the ICTY's work. In videos and transcripts stored on terabytes of servers, prosecutors make motions, defense counsel object to them, judges decide them, and a small army of clerks read evidence into the record that may support or refute them. The Tribunal may conclude its final cases within the coming years, its record one of legal progress and deeply contested narratives, but its existence - together with the archives of the ICTY's sibling institution, the UN International Criminal Tribunal for Rwanda (ICTR) - will continue on in an archives of international judicial proceedings.

The Tribunal's archives, in short, hold the records of convictions and acquittals, prosecution and defense arguments. The archives are a 'collection of records that have been generated in the course of the judicial proceedings' (Adami 2007). But it is not merely a record of criminality; it is also a record of innocence, excuse, recrimination, blame - indeed, much of the emotion that fueled the wars themselves. So how should we conceptualize the vast archives of the ICTY? What audiences ought it address or take into account, if it ought to at all? What stories ought it capture? What purposes might it pursue? How might the legacy of the ICTY fare once its primary work has been completed? Should we conceive of its work as 'completed' when all trials and appeals have been concluded and all sentences served? Or should it turn to a new phase of work once the 'documentation' phase of trial and judgment has run its course? If its work continues on, in some form, what is the nature of that work? How should archivists responsible for the ICTY records treat, appraise, and organize the material?

This essay introduces some of the questions surrounding the disposition of the ICTY archives. I have limited aims, focusing mainly on introducing the topic and presenting some ideas for how to address it, given decisions already made. The first section situates the Tribunal archives in historical, political, and legal contexts and highlights a critical problem: the ICTY, seen very much as a political actor in the postwar Balkans, has struggled to assert its identity as a neutral fact-finder and adjudicator of guilt and innocence. Its shifting images as a partisan (among Serbs and Croats) or a protector of senior officials (recently, among victims and activists), attacked from multiple angles, have important consequences for the long-term functions of its archives. The second 


\section{DRAFT of 17 July 2014}

section turns to the nature of the records held by the ICTY and claims for their disposition. A third section offers several ways to conceptualize the ICTY archives.

\section{Background: A Short History of the ICTY's Agenda}

War came to the Balkans in 1991, as the end of the Cold War uncorked nationalisms across the region and enabled demagogic politicians - such as Slobodan Miloševic in Belgrade, Franjo Tudjman in Zagreb, and Radovan Karadzic in Pale/Sarajevo - to exploit them to maintain and extend their positions of power (Glenny 1996). European powers and the United States found themselves unable to muster the resources and the will to end the violence, and by the middle of 1992, the war in Bosnia in particular seemed especially brutal. The UN Security Council set up 'safe havens' that proved unable to provide safety to the victims of the conflict in Bosnia, and otherwise it did nothing forceful to seek to end the war or its most terrible manifestations. In the face of its incapacities, the UN instead turned to the idea of justice (Bass 2002; Power 2002).

On May 27, 1993, the UN Security Council adopted Resolution 827, establishing the ICTY to investigate and prosecute war crimes, crimes against humanity, and acts of genocide that allegedly had taken or were taking place on the territory of the former Yugoslavia. It aimed to highlight the crimes that were coming to light across the region and to emphasize its condemnation of serious violations of international humanitarian law. It sought to establish a tribunal that would 'put an end to such crimes and . . . bring to justice the persons who are responsible for them,' and 'contribute to the restoration and maintenance of peace’ (United Nations Security Council 1993). These purposes resonated with ideas of criminal justice, on the one hand, and the threshold for Council power under Chapter VII of the UN Charter, identification of a threat or breach of peace and security. The first president of the ICTY, Judge Antonio Cassese, took the purposes a step further; his words in the Tribunal's first Annual Report deserve reproduction at some length:

'16. The role of the Tribunal cannot be overemphasized. Far from being a vehicle for revenge, it is a tool for promoting reconciliation and restoring true peace. If responsibility for the appalling crimes perpetrated in the former Yugoslavia is not attributed to individuals, then whole ethnic and religious groups will be held accountable for these crimes and branded as criminal. In other words, "collective responsibility" - a primitive and archaic concept - will gain the upper hand; eventually whole groups will be held guilty of massacres, torture, rape, ethnic cleansing, the wanton destruction of cities and villages. The history of the region clearly shows that clinging to feelings of "collective responsibility" easily degenerates into resentment, hatred and frustration and inevitably leads to further violence and new crimes.

17. Thus the establishment of the Tribunal should undoubtedly be regarded as a measure designed to promote peace by meting out justice in a manner conducive to the full establishment of healthy and cooperative relations among the various national and ethnic groups in the former Yugoslavia' (United Nations 1994). 
Cassese, reflecting a commonly held view in the early days of the ICTY, driven as much by moral, ethical, and policy commitments as by empirical support, imagined the Tribunal playing an ambitious role during and after conflict. It would be a tool for reconciliation, 'true peace,' accountability, and international cooperation.

Given the continuing levels of separation and recrimination in Bosnia today, it would be difficult to argue that the Tribunal met (or even pursued) Cassese's goals, reinforcing the sense that broad social or political change cannot and should not be the goals of international justice. As Martha Minow stated in her influential study of responses to mass atrocity, 'Reconciliation is not the goal of criminal trials except in the most abstract sense' (1998, p. 26). The same may be said about deterrence, for which the evidence - at least at the international level - has long been thin (Wippman 1999; Cronin-Furman 2013). As the reality of criminal trials emerged, as the docket grew, and as the struggle for cooperation from Belgrade and Zagreb intensified, the Tribunal itself moved away from the rhetoric of reconciliation and peacemaking in favor of the clear mandate of criminal trials assigning individual accountability. Bronwyn Leebaw notes, "The utopian rhetoric that characterized human rights legalism in the 1990s would eventually give way to a more modest and nuanced set of claims” (2011, p. 55). Mark Osiel challenged the Cassese position implicitly: 'A criminal trial . . . is not welldesigned for establishing society-wide consensus over the interpretation of tremendously controversial acts' (1999a, p. 248). Osiel's view had already become the emerging approach of the Tribunal, avoiding an effort to bring about broad consensus over the national scope of responsibility and instead focusing on liability case by case. Cassese's first annual report of the ICTY recedes as a relic of a particular moment as later reports highlight the work of the Court and its needs from the UN and its member states. As the Tribunal's second president, Judge Gabrielle Kirk MacDonald, noted at the opening of the 1996 trial of Dusko Tadić, the 'sole raison d'etre' of the ICTY was 'ensuring that this first trial will be conducted as fairly and as expeditiously as possible with justice being both done and being seen to be done' (United Nations International Criminal Tribunal for the Former Yugoslavia 1996). This became the ethos of the Tribunal as it indicted another 160 persons. Examine the succeeding annual reports and one will find a focus on specific trials, cooperation, enforcement, funding, outreach, and so forth - and very little, if anything, about peace and reconciliation. (ICTY annual reports are collected at http://www.icty.org/tabs/14/1.)

And yet, the recognition that even international criminal trials serve one principal purpose - assigning guilt or innocence to those accused of serious crimes - only thinly masks the reality that trials, as important as they may be, are an ultimately unsatisfying way to deal with such massive crimes as genocide and crimes against humanity, crimes of such scope that individual legal liability shrinks in relation to political, social, bureaucratic, and moral responsibility. Osiel captures the dilemma when he writes, 'When it narrows its lens to the person in the dock, the law risks underestimating the significance of his or her deeds, for their gravity is comprehensible only when seen in relation to those of many others...' (2009b, p. 3). The claim that follows is not merely for some broad historical statement of facts, though UN Secretary General Ban Ki Moon, as 


\section{DRAFT of 17 July 2014}

recently as 2011, argued that 'the tribunals' efforts in gathering and categorizing large amounts of documentation ensure that history cannot be distorted later for political ends' (United Nations Secretary General 2011). It is also a claim for 'the creation of transparent court records that simply speak the truth to the relevant audiences' (Minow 1998, p. 125). Judicial records may 'speak the truth' to an audience prepared to receive their messages, such as those associated with international criminal justice in The Hague, New York, Geneva and elsewhere. But can they speak to the communities in which the war crimes, the crimes against humanity, the genocide took place, where the victims and perpetrators live? Minow doubts that such records have that power on their own: 'The idea of accessible court records that speak for themselves . . . is problematic' (Ibid). Court records contain a complex mix of substantive, procedural and technical decisions, honest and prevaricating testimony, objective and biased material, and so forth, such that their mere existence is hardly enough to tell a truthful story of mass atrocity. The ICTY's history highlights that something more than simple accessibility will be needed for its judgments and evidence to penetrate the dense fog of feeling and perceptions that hangs over the Balkans nearly twenty years after the wars there ended.

The early trials of the ICTY attended to low- and mid-level participants in atrocities, mainly in Bosnia and Croatia, highlighting specific crimes such as killings and rapes, unlawful detention, attacks on civilians, and other categories of war crimes and crimes against humanity and, ultimately, genocide. One by one, the cases brought out the narratives of individual victims and perpetrators, as witnesses told often terrible stories from their experiences in the war. Prosecutors also used the cases to deliver a narrative of broader responsibility, showing how municipal authorities, military organizations, and political parties were organized to support and defend activities that amounted to violations of the law of armed conflict. They brought not just local witnesses to alleged crimes but also military experts, diplomats, journalists, historians, and others to share what they saw and know. Defense counsel, validating Osiel's claim that the Tribunals would be forums for 'competing historical accounts,' developed their clients' own counter-narratives (1999a, p. 248). Each case thus became not only a prosecution of a specific individual or individuals, but a contested history in miniature of the background behind and broader responsibility for the crimes.

Most of the indictees were Serbs. It was expected that investigations and prosecutions of lower level perpetrators would lead to, and make it easier to prosecute, the senior perpetrators. However, they were extremely resource-intensive, and over time, the Tribunal and the Security Council found it necessary to approach only senior perpetrators, using different methods. As time went on, therefore, the ICTY focused its attention on more senior level alleged perpetrators, reaching not only the Bosnian Serb political leadership (Karadžić, Krajišnik, Plavšić) and military brass (Mladić, Krstić) but the central leaders in Serbia proper (Milošević, Milutinović, Perišić) and crimes in Kosovo as well. It brought charges against senior military officials in Croatia (Blaškić, Gotovina) and Bosnia (Rasim Delić) without seriously disturbing the substantial focus on crimes against Bosnia's Muslim community. These senior-level prosecutions should have been seen as an extension of Justice Robert Jackson's dictum at Nuremberg that 'crimes always are committed only by persons’ (Jackson 1945). Yet the trials of senior-level 


\section{DRAFT of 17 July 2014}

perpetrators heightened the historical and inter-communal contestation, seen most strikingly in the Milošević prosecution, in which the defendant sought to tell a broad counter-story of non-Serb responsibility (Boas 2007). The Security Council ultimately decided that the Tribunal, in order to conclude its operations by a reasonable date, should focus only on senior officials most responsible for the most serious crimes (United Nations Security Council 2004).

From the time of its founding, the ICTY has had a difficult relationship with governments and citizens in the region, especially in Belgrade and Zagreb, while at the same time engaging the hopes and support of victims of the wars. The focus on senior officials drove the prosecutions to highlight the broader mechanisms of criminal behavior, casting blame not upon 'trigger pullers' but on the broader policy apparatus that directed, facilitated, or supported crimes. Attention at the level of government policymaking drove prosecutors to tell broader 'historical' stories, which likely hardened the attitudes of opposition. The Tribunal enjoyed the strong support of the United States and European Union, which imposed economic and diplomatic sanctions as long as Serbia and Croatia failed to cooperate. But the ICTY became a hot political issue in the domestic politics of the region, and the image of the Tribunal sustained substantial damage during the years of criticism over Croatia's and Serbia's lack of cooperation. A 2009 survey of attitudes toward the Tribunal in Serbia, conducted by the Organization for Security and Cooperation in Europe (OSCE), showed that $72 \%$ of those living in Serbia had a very negative or mostly negative view of the ICTY; among Serbs only, that figure rose to 78\% (Organization for Security and Cooperation in Europe 2009). By similar numbers, the population largely believed that ICTY trials did not contribute to reconciliation. Attitudes in Croatia at that time, though not subject to the survey, likely would have shown a similar attitude of opposition, if less pronounced, because of the investigation and prosecution of those identified as war heroes, such as General Ante Gotovina (Klarin 2009). The popular Croatian Prime Minister Ivo Sanader, at a 2007 commemoration of the 1995 Operation Storm, a central focus of the ICTY's trial of Gotovina and others, insisted that 'no one is going to write Croatian history but us' (Pavlakovic 2007, p. 1).

Despite the negative attitudes of public opinion in Serbia and Croatia, where government and politics helped whip up opposition, the attitudes among Bosniaks and Kosovar Albanians could be counted on for continued support. That base of support, however, has been shaken by decisions that involve acquittals of key figures in the wars. The acquittals of Croatian General Ante Gotovina (extremely surprising) and Kosovar leader Ramush Haradinaj (expected) in the fall of 2012 reinforced the Serb perception of a biased ICTY, while perhaps providing a modest boost in perception among Kosovar Albanians and Croats. Then, the acquittals of Momčilo Perišić, former chief of staff of the Serbian army, in March 2013, and Franko Simatović and Jovica Stanišić, leaders of the security services in Serbia during the war, in May of 2013, undermined the support previously provided by victims. All three were widely understood to have played major roles in Belgrade's engagement in the wars in Bosnia and Croatia. The Appeals Chamber in Perišić, however, applied a controversial (if legally supportable) standard to determine whether the accused aided and abetted war crimes across the border, finding that Perišić 


\section{DRAFT of 17 July 2014}

did not meet that standard. A trial chamber applied the standard to Stanišić and Simatović, finding that, although the crimes in Bosnia were proven and heinous, it was not proven that the accused met the standard for aiding and abetting liability. In both cases, as well as Gotovina, few doubted that the accused played a role in the wars, in all likelihood a deeply problematic one. But was it a criminal one? The Tribunal found that the criminal law standard was simply not met.

Right or wrong, that standard and the acquittals generated confusion and anger among victims and advocates. Consider, for instance, the reaction of Refik Hodzic, a well-known and respected figure through his independent work in Bosnia and work with the ICTY and the International Center for Transitional Justice. He tweeted shortly after the Stanišić and Simatović judgment, "I have no idea what to think about \#ICTY anymore. It has shaken the foundation of my understanding of justice and judicial truth" (Hodzic 2013). Hodzic's attitude was widely shared. Nenad Golcevski of the Humanitarian Law Center in Belgrade asserted that the ICTY 'lost respect' and 'lost credibility, in the region and internationally. We feel as though the rug has been pulled from beneath us' (Holligan 2013). The Belgrade-based observer Bogdan Ivanisevic wondered why 'the region's best and brightest are giving up' on the ICTY, and he named an impressive list of human rights activists who seemed to have lost hope in the Tribunal (Ivanisevic 2013). Beyond Belgrade, Ken Roth, the executive director of Human Rights Watch and one of the leading human rights voices internationally, harshly criticized the Tribunal, saying it 'could cripple future efforts to prosecute senior officials responsible for human rights crimes’ (2013).

The Tribunal's winding-down should be a moment to celebrate its central role in reinvigorating international criminal justice, but instead it faces controversy and doubt. The long-held attitudes of opposition to the Tribunal because of perceived bias, particularly in Serbia but also Croatia and Bosnian Serb communities, are unlikely to erode anytime soon. The new attitudes of regret and disappointment, among victims and organizations that support them or their families, may yet be reversed by further convictions (such as could result from the ongoing trials of Radovan Karadzic and Ratko Mladic). Moreover, given the Tribunal's collection of vast evidence of criminality and mass abuse of the rights of civilians during the wars of the 1990s, the traditional supporters of the ICTY may return to a position of support, to see the ICTY's legacy as more beneficial to their goals than they might now think likely. That said, the apparent legal difficulty of holding Belgrade officials liable for the crimes in Bosnia has undermined the commitment of many key supporters who saw Serbia's involvement as an essential historical component of the crimes in Bosnia. It is easy to see their disappointment as a representation of an underlying view that the ICTY should not only adjudicate criminal responsibility but also verify broader narratives about moral and political responsibility for massive human rights abuses.

\section{The ICTY Records}

The United Nations has identified three categories of records held by the Tribunal: judicial, amounting to all of the material related to investigations, trials, 


\section{DRAFT of 17 July 2014}

appeals, and so forth; non-judicial but generated as part of the judicial process, such as minutes or results from meetings of the judges; and administrative, such as personnel records (United Nations 2009). Trudy Huskamp Peterson categorizes the records further, noting that judicial records should be understood in terms of who created them, especially the Office of the Prosecutor, Chambers, and Registry offices such as those responsible for victims and witnesses, legal aid, defense counsel, and outreach (Peterson 2006). The judicial category alone includes vast amounts of material. In 2009, the UN noted,

'[The] ICTY has estimated that the total of its physical records by the end of 2010 will require 3,704 shelf metres and that its electronic records will increase by as much as 8,000 terabytes or more (which will require specific server rooms). The projected storage needs for paper records for ICTR by 2010 is 2,336 shelf metres, while the Tribunal has estimated the total amount of digital storage requirements at 1,020 terabytes by 2010 (which will require specific server rooms)' (United Nations 2009, p. 14).

By contrast, consider that the archives of the International Military Tribunal at Nuremberg, at the time considered to be a 'tremendous amount,' involved a mere 2500 pages of judgments, 134,765 pages mimeographed, and ten-thousand printed pages (Kempner 1950, p. 447). The ICTY material includes but is not limited to witness testimony transcripts and videos, along with supporting documentary evidence; satellite imagery; signals intercepts; diplomatic correspondence or reporting and other journalism in digital, video, and written formats; personal artifacts; photographs, videos and so forth of victims and others from the region; witness and victim interviews, personal data, documentation; official documents, such as military personnel and logistics records; minutes of political meetings; indictments prepared by the Office of the Prosecutor and approved by a panel of judges; judgments of the chambers at the trial and appeal levels; judicial orders on matters of substance and procedure; transcripts from proceedings; correspondence between the Tribunal and governments or other information-providers, or between Tribunal officials and defense counsel, etc.; outreach materials, such as records of 'town hall' discussions in the region, trainings of lawyers and judges, and so forth; work product, such as notes of investigators, lawyers, and judges, and draft motions, judgments, and orders; internal guidance, such as policies and rules governing investigations, prosecutions, conflicts of interest, interaction with witnesses, and much more.

Many other kinds of documents exist, but this partial list gives an idea of the breadth of the material and the likely interest to a range of audiences (Emmerson 2011). This also reflects only the category of judicial records. The administrative records are also vast, recording basic budgetary issues, personnel, buildings, acquisitions, and other documents that together tell the story of the growth of the Tribunal.

The public already enjoys access to a vast array of these documents, provided they are available in documentary form and do not compromise material provided in confidence (so-called Rule 70 material provided by governments and other entities), necessary to protect the identities of witnesses or other participants, or otherwise 


\section{DRAFT of 17 July 2014}

privileged or protected as a matter of law. Both the ICTY and the ICTR have opened much of the public record to access by anyone interested in viewing and using it. It is not clear how much more is held under rules of confidentiality, but it is likely to be considerably less than the categories of 'work product' or artifacts. The ICTY's website includes official and public documents pertaining to each case. It also includes a search engine to allow access to a huge range of resources, such as evidence, video, and so forth. ICTY public records number more than 150,000, according to the ICTY, and may be searched at http://icr.icty.org/default.aspx.

The problem is less identification of the materials than disposition and future use and functions. For the moment, the archives is an active one that supports ongoing trials and appeals; the UN considers it also valuable for future work related to those serving sentences, protection of victims and witnesses, and prosecutions by national authorities (United Nations 2009). For that reason, the Security Council decided that the Tribunal's records will be under the purview of the Residual Mechanism, a transitional body that will deal with Tribunal business as the Tribunal itself completes its trial and appellate proceedings (United Nations Security Council 2010). At the same time, however, the Council asked the Tribunal to work with the countries of the former Yugoslavia and other interested entities to 'facilitate the establishment of information and documentation centres by providing access to copies of public records of the archives' (Ibid). This hardly answers the question of disposition, since 'public records' addresses only one aspect of the ICTY archival holdings.

\section{Concepts of an ICTY Archives}

The huge quantity of material has triggered an active discussion over the ICTY archives (Ketelaar 2009; Campbell 2013). The UN's 2009 report addressing the archives issues returned to the Cassese model of the role of the Tribunal. Dormant for so long, the notion of the Tribunal as a tool for reconciliation and peace comes through explicitly. The report says:

'It should be recalled that each Tribunal [ICTY and ICTR] was established as a measure under Chapter VII of the Charter to contribute to the process of national reconciliation and to the restoration and maintenance of peace in the affected countries. [reference omitted] The archives are tools for fostering reconciliation and memory' (United Nations 2009, p. 55).

This overstates the Security Council's goal of 'national reconciliation,' misstating the actual language of the early Council resolutions, but it does return the Tribunal to the vision Cassese expressed. By doing so, the UN suggests a kind of temporal frame around archival use: either, in the medium-term, the documents will be used by investigators, prosecutors, and other criminal law professionals (as well as some related to the UN institutionally), or, in the long-term, the archive will be used for regional and national 'reconciliation and memory.' The UN, which highlights its legal ownership of the archives, puts it this way: 


\section{DRAFT of 17 July 2014}

'The primary value of the Tribunals' records will progressively diminish over time as the residual functions are no longer needed. Thereafter, the secondary value of the archives, namely, their memory, education and research value, will progressively prevail. The content of the Tribunals' archives is significant to victims, witnesses and their families and, more widely, the populations of the affected countries. Government officials, other international tribunals and courts, such as the International Criminal Court, journalists, historians, legal researchers, political scientists and persons interested in memorializing an event or creating educational materials, may also seek access to the Tribunals’ records’ (Ibid, p. 15).

The UN's vision for the archives, though focused on a multiplicity of audiences, nonetheless fails to articulate the array of purposes that might be served by the archives. Most importantly, its advocacy for a conciliatory function assumes that the archives itself contains only uncontested facts, as if adjudicated material must necessarily serve as the cornerstone of future use. It neglects the fact that the judicial output of the Tribunal, in particular the judgments at the trial and appellate levels, not only contain adjudicated facts but also factual and legal interpretation. Kirsten Campbell provides an analysis of the ideas surrounding the archives as a 'legal memorial' (2013, passim). But as noted above, the adjudications themselves have proven extraordinarily divisive and contested. Even today, more than twenty years after the establishment of the ICTY, few 'facts' are considered uncontested by people in the region. It may be that, case by case, individuals may acknowledge the legitimacy of a particular outcome, but the overall narrative of national and community responsibility remains largely unchanged from where it began, the wars becoming embedded in national identity (Stover and Weinstein 2004). At this point in time, it is difficult to imagine the archives developing a 'reputation' independent of the ICTY itself, which means that the archives itself could become a contested institution filled with contested memories. 'National reconciliation' as a purpose of the archives raises the bar too high. In fact, 'reconciliation' is likely to trigger competition for the appropriate foundational ground on which communities ought to reconcile.

Debates over the archives have, to date, largely focused on the question of location, assuming that they will have a reconciliation-and-memory purpose. To some extent the location question has been resolved, at least for publicly available and digitized records, as national information centers have been identified for individuals to seek access directly to the archives. The Humanitarian Law Centre in Belgrade, for instance, already has duplicated significant portions of the archives as 'a valuable source of information, which can help in initiating criminal proceedings against perpetrators of war crimes, triggering social dialogue about the past, and education of young people about the past'(Humanitarian Law Center 2014). Other centers in Zagreb and Sarajevo will be making similar records available to their local communities. But the location issue does not work for all of the documentation, such as artifacts and confidential records. Moreover, the location debates allow us to avoid the broader questioning of what purposes the archives might actually serve and the degree of archivist involvement in appraisal that may be required. For instance, as much as locating the material close to the communities may provide local actors with direct access to archival materials, multiple 


\section{DRAFT of 17 July 2014}

locations may also advance the cause of competing memories, to the extent that communities in Belgrade, Sarajevo, and Zagreb deploy the archives to tell different stories that may in fact be at odds with one another - as a judicial archives provides the material to do just that.

It may be correct to think of the archives as an endlessly useful repository of documents and artifacts from the work of the ICTY. However, some appraisal may be essential in order to ensure that the archives serve purposes beyond the ones identified by the UN. I do not highlight these potential purposes merely to suggest ways in which audiences may engage the archives. I also want to suggest that archivists, or policymakers designing specific archival research tools or research facilities, ought to appraise and organize the records so as to be consistent with the intention of the founding of the ICTY itself. Thus, purpose-driven appraisal might include the four principal ones that follow:

An Archives of History and Experience: This is closest to the idea of the archives as a repository for historical memory, a place that holds truth if we understand truth as 'a form of shorthand to denote a series of occurrences, plural by natural, which, while ultimately unknowable in their entirety, can be partially uncovered' (Caswell 2010). Tom Adami and Martha Hunt argue that international tribunal records may serve purposes of both reconciliation and historical memory (Adami and Hunt 2010). At the community level, the archives' collection of video, photographs, and other imagery from the wars in the Balkans expose individual experiences. Whether they are 'true' or served to validate a prosecution or defense of a particular accused may be beside the point; they reflect lived experience of the people of the region.

Eric Ketelaar makes a powerful argument for the Tribunal records as providing the foundation for a 'living archive,' capacious enough in spirit and purpose to allow for challenge and contestation (2009, passim). The archive, in his words, is a 'space to escape from a monolithic truth, history and memory, by allowing questioning myth and rationality - including the myth and rationality contained in the archive' (Ibid). While the Balkans bear the scars of splintered memory, a different and often contradictory narrative propounded by each ethnic group, Ketelaar suggests:

'The archives of the ICTY, however, cannot be split up according to the ethnic provenance of perpetrators, victims and witnesses. It is a joint albeit a contentious heritage that should be accessible from any of the places in former Yugoslavia (and from anywhere in the world) where people live who want to use the archives. The contentiousness of the archive might even prove beneficial because it can show 'how people can live with continuing disagreements about what exactly happened in the past and why...' [citation omitted] . . . I believe that the risk of contentiousness of the archives should be taken, too' (Ibid, p. 122).

Ketelaar concludes by arguing that '[t]he risk of 'ethnization' (or exclusiveness) of memories may be abated by giving each community in the former Yugoslavia not just a 


\section{DRAFT of 17 July 2014}

share in a joint heritage, but by making each community a co-custodian of the living ICTY archives, constantly challenged and challenging' (Ibid, p. 124).

Ketelaar's optimistic position in favor of a shared or multiple archives, available across national and ethnic boundaries, not only has the power of openness and rationality behind it, but it also has the authority of reality. The ICTY will be making as much of the records publicly accessible as possible, apart from those subject to individual witness protection and other legitimate claims to confidentiality, and there is simply no central figure in the Tribunal or broader UN universe with the authority or power to verify one particular narrative over another, apart from (perhaps) the final judgments of the appellate chambers. The documentary material that makes up the judicial records will be available to be challenged and contested because, as a matter of fact, that is the only plausible way in which the United Nations might make them available.

And yet it is precisely contestation of fundamental facts - individual responsibility for atrocities, for instance - that international justice ultimately seeks to avoid. International justice may focus on the specific criminal behavior of individuals brought to trial, but the accretion of specific crimes, demonstrating patterns of criminal behavior, is also designed to constrain the ability to deny the atrocities themselves (Orentlicher 2008). Contestation will collide directly with this notion of truth-telling, just as deniers of Nazi atrocities collide with historical truth. Contestation is, however, unavoidable. Archivists will be under significant pressure, certainly within the UN system, to adopt the role of arbiter of truthfulness, appraising the ICTY records in such a way that highlights the conclusions and patterns of criminality as found in judgments of the chambers. They will be expected by many to construct an archives that speaks for the records rather than an archives that speaks for itself. Or as Ketelaar himself has emphasized, archivists, like museum curators, must engage in a process of contextual reenactment as part of the process of archival construction and appraisal (2001). Whether they take on such social responsibilities will frame the historical nature of the archives (Jimerson 2007). Outside a UN archival system, however, archivists and historians in Belgrade, Sarajevo, and Zagreb will almost certainly be under varying pressures to construct and narrate in such a way that is consistent with national or local narratives. The future of the ICTY records thus faces a long-term state of contestation that will neatly mirror the contestation over the Tribunal's judicial process itself.

An Archive of Process: The Tribunal, together with the ICTR, invented the modern law of international criminal procedure and evidence. That law is collected in the decisions of the Tribunal over time, but the end-point of a decision or order fails to capture the intricacies of the process, the choices left unmade, the paths not taken, and so forth. Law on the books appears as if received from on high, but the archives can help achieve a fuller memorialization of the choices made and the reasons behind them.

On the surface, a process-oriented purpose should provoke lighter recrimination and contestation than one focused on history and memory. Nonetheless, 'procedural' issues have posed significant challenges to the ICTY over time, and they are likely to persist in the archival phase of the Tribunal. A significant set of process issues will 


\section{DRAFT of 17 July 2014}

appeal to technical experts and legal historians seeking to broaden professional understanding of the evolution of international criminal process, such as issues pertaining to the availability of documentary evidence over live testimony, case management, judicial functions, and so forth. An examination of the range of procedural debates, however, suggests that process could be subject to similar levels of contestation and will also require significant efforts of archival appraisal. For instance, due process norms related to fair trials and the rights of the accused, the length of trials, the equality of arms between prosecution and defense, the availability of pro se representation (i.e. representing oneself), the execution of arrest warrants, disclosure of exculpatory and other kinds of material evidence, and witness protection, to name a few, implicate significant attitudes toward the ICTY as a whole. Still, a transparent and accessible archives should bring to life the arguments and advocacy that led to judicial decisions that have framed much of international procedure today.

An Archives of Jurisprudence: Similar to the process points, the ICTY and ICTR developed the jurisprudence of international criminal law, a practically unknown and inert field of law before 1993, captured mainly by the Nuremberg trials, the follow-on national trials of Nazis, the Geneva Conventions of 1949, and a hodge-podge of national trials over the course of several decades. The Tribunal has produced judgments of hundreds of pages each, volumes of law that are often difficult to penetrate and explain. An archives of jurisprudence would capture the nature of that law, the purposes behind it, the proceedings that led to it, the contestation involved. One could imagine an archives that is organized around substantive law-war crimes, crimes against humanity, acts of genocide-and takes the audience through each particular criminal prohibition, highlighting decisions made by prosecutors and defendants in addition to the decisions of judges. Such an archives could not shrink from the fact that the judicial conclusions ultimately reflect interpretation of law, thus opening the Tribunal up to a long-term (perhaps never-ending) process of reconsideration and challenge.

An Archives of an Institution: The ICTY is many things, but it is primarily and foundationally an institution of the United Nations, a subsidiary organ of the Security Council, a transmitter of norms, an interpreter of law, a progenitor of contemporary international criminal law institutions, especially the International Criminal Court. Its historical records will be subject to national and local contestation, while its procedural and substantive legal innovations provide the groundwork for the development of a substantial field of legal study. For these two purposes, the role of the archives will be indispensible. However, the archives also captures the reality of the ICTY as an international organization created by the United Nations. Very little literature exists to capture the lessons learned by those involved in the establishment of the Tribunals, lessons that will have particular resonance for the UN in future institution-building and for similar judicial institutions such as the ICC. It would be a great loss indeed if, in the effort to shape an archives that serves one or more of the above three purposes, the institutional perspective gets lost, ignored, or devalued.

The archives may serve an institutional-historical function, something available for reflection by those who think about, design, create, implement, and manage 


\section{DRAFT of 17 July 2014}

international organizations, especially international courts. Even noting this, however, allows us to reflect on an important point, namely, that the ICTY has essentially created the records that will constitute the permanent archives. As such, the United Nations holds a real stake in the future of the archives, not merely as manager or protector of the variety of privileged material but as a party interested in ensuring that there is broad access to study the origins and development of the Tribunal.

\section{$\underline{\text { Conclusion }}$}

This essay has sought to provide some background and context for the discussions concerning the records and archives of the ICTY. In considering the future value and functions of the archives, I have tried to emphasize that factual and legal adjudication has not eliminated the element of contestation and protest. Populations in the region, including or especially their political leaders, either perceive or portray the ICTY as a partisan actor drawing illegitimate conclusions. At the same time, recent judgments have sparked outrage among those who typically and historically support the Tribunal. Opposition will not disappear with the conclusion of the ICTY's trials and appeals. Should those developing the archives take such opposition into account? At the very least, the contested nature of the Tribunal's present work and future legacy should trigger some broad thinking about the functions of the archive, beyond the politically constructed notions of reconciliation. At the same time, to the extent reconciliation remains a desired purpose, those thinking about the archives should carefully assess how a Tribunal of such a divisive reputation can, in its archival form, achieve goals unattainable during its 'primary' lifetime. It may be possible, with appraisal, to achieve those goals, but they need to be grounded in a theory of the archives that is faithful to the reality of its difficult history.

\section{$\underline{\text { References }}$}

Adami TA (2007) "Who will be left to tell the tale?” Recordkeeping and international criminal jurisprudence. Arch Sci 7: 213-221

Adami TA and Hunt M (2010) Reconciliation in Regions Affected by Armed Conflict: The Role of Archives. In: C. Avery and M. Holmlund (eds) Better Off Forgetting? Essays on Archives, Public Policy, and Collective Memory. University of Toronto Press, Toronto

Bass G (2002) Stay the Hand of Vengeance: The Politics of War Crimes Tribunals. Princeton University Press, Princeton

Boas G (2007) The Milošević Trial: Lessons for the Conduct of Complex International Criminal Proceedings, Cambridge, United Kingdom

Campbell K (2013) The Laws of Memory: The ICTY, the Archive, and Transitional Justice,. Journal of Social and Legal Studies 22:247 - 269. 
Caswell M (2010) Khmer Rouge archives: accountability, truth, and memory in Cambodia, Arch Sci 10: 25 - 44.-44

Cronin-Furman K (2013) Managing Expectations: International Criminal Trials and the Prospects for Deterrence of Mass Atrocity. International Journal of Transitional Justice: 1 $-21$.

Emmerson E (2011) How Best to Preserve the Records of the ICTY. In: Steinberg, R., (ed) Assessing the Legacy of the ICTY. Brill, The Hague

Glenny M (1996) The Fall of Yugoslavia. Penguin, New York

Hodzic, R. Twitter. May 30, 2013.

https://twitter.com/ledenik1/status/340192606875172865.

Holligan A. ICTY Hague court in turmoil amid claims of manipulation. BBC. 20 June, 2013

Humanitarian Law Center (2014). Archive of ICTY trials. Undated press release. http://www.hlc-rdc.org/?page_id=17545\&lang=de.

Ivanisevic B (2013). Falling Out of Love with the Hague Tribunal. Balkan Insight. 11 June 2013. Available at http://www.balkaninsight.com/en/article/falling-out-of-lovewith-the-hague-tribunal.

Jackson R (1945). Opening Statement before the International Military Tribunal, November 21, 1945. Trial of the Major War Criminals Before the International Military Tribunal 2: 98-155

Jimmerson R (2007). Archives for All: Professional Responsibility and Social Justice. The American Archivist 70: 252 - 281.

Kempner R (1950). The Nuremberg Trials as Sources of Recent German Political and Historical Materials. American Political Science Review 44: 447 - 459.

Ketelaar E (2001). Tacit Narratives: the Meanings of Archives. Arch Sci 1: 131 - 141.

Ketelaar E (2009). A living archive, shared by a community of records. In: Bastian J and Alexander B (eds) Community Archives: the Shaping of Memory, pp. 109 - 132. Facet, London

Klarin, M (2009) The Impact of the ICTY Trials on Public Opinion in the Former Yugoslavia. Journal of International Criminal Justice 7:89 - 96

Leebaw, B (2011). Judging State-Sponsored Violence, Imagining Political Change. Cambridge.

Minow M (1998). Between Vengeance and Forgiveness. Beacon, Boston.

Orentlicher D (2008). Shrinking the Space for Denial: The Impact of the ICTY in Serbia. Open Society, New York.

Organization for Security and Cooperation in Europe (2009). Public perception in Serbia of the ICTY and the national courts dealing with war crimes. Belgrade. Available at http://wcjp.unicri.it/proceedings/docs/OSCESrb_ICTY_Perception_in_Serbia.pdf . 


\section{DRAFT of 17 July 2014}

Osiel M (1999a) In: Hesse and Post (eds) Human Rights in Political Transitions: From Gettysburg to Bosnia, pp. 217 - 262

Osiel M (1999b) Making Sense of Mass Atrocity 3. Cambridge, United Kingdom

Pavlakovic V (2007) Eye of the Storm: The ICTY, Commemorations and Contested Histories of Croatia's Homeland War. Available at http://www.wilsoncenter.org/sites/default/files/MR347Pavlakovic.doc

Peterson TH (2006) Temporary Court, Permanent Records. U.S. Institute of Peace, Washington

Power S (2002) 'A Problem from Hell’: America in the Age of Genocide. Harper, New York

Roth K (2013). A Tribunal’s Legal Stumble. The New York Times, July 9, 2013

Stover E and Weinstein H (2004) My Neighbor, My Enemy: Justice and Community in the Aftermath of Atrocity. Cambridge, United Kingdom.

United Nations International Criminal Tribunal for the Former Yugoslavia (1996). ICTY, The Prosecutor v Tadić (Case IT-94-1-T), Transcript of 7 May 1996 http://www.ictytranscripts.org/trials/tadic/960507IT.htm

United Nations (1994). Report of the International Tribunal for the Prosecution of Persons Responsible for Serious Violations of International Humanitarian Law Committed in the Territory of the Former Yugoslavia Since 1991, UN DOC. S/1994/1007, 29 August 1994

United Nations (2009). Secretary General Report to the UN Security Council, UN Doc. S/2009/258

United Nations (2011). Secretary General Report to the UN Security Council, UN Doc. S/2011/634

United Nations Security Council (1993). Resolution 827, S/RES/827, May 25, 1993

United Nations Security Council (2004). Resolution 1534, S/RES/1534, March 26, 2004

United Nations Security Council (2010). Resolution 1966, S/RES/1966, December 22, 2010

Wippman D (1999) Atrocities, Deterrence, and the Limits of International Justice. Fordham International Law Journal 23:473 - 488 